This is the final peer-reviewed accepted manuscript of:

Monica Caffara, Sean A. Locke, Ali Halajian, Wilmien J Luus-Powell, Deborah Benini, Perla Tedesco, Gyrhaiss Kapepula Kasembele, Maria L. Fioravanti 2019. Molecular data show Clinostomoides Dollfus, 1950 is a junior synonym of Clinostomum Leidy, 1856 , with redescription of metacercariae of Clinostomum brieni n. comb.

The final published version is available online at: https://doi.org/10.1017/S0031182018002172

Rights / License:

The terms and conditions for the reuse of this version of the manuscript are specified in the publishing policy. For all terms of use and more information see the publisher's website.

This item was downloaded from IRIS Università di Bologna (https://cris.unibo.it/)

When citing, please refer to the published version. 


\section{Molecular data show Clinostomoides Dollfus, 1950 is a junior synonym of Clinostomum Leidy, 1856, with redescription of metacercariae of Clinostomum brieni $\mathbf{n}$. comb.}

\begin{tabular}{|r|l|}
\hline Journal: & Parasitology \\
\hline Manuscript ID & PAR-2018-0318.R2 \\
\hline Manuscript Type: & Research Article \\
\hline Author: & n/a \\
\hline Complete List of Authors: & $\begin{array}{l}\text { Caffara, Monica; University of Bologna, Veterinary Medical Sciences } \\
\text { Locke, Sean; University of Puerto Rico, Department of Biology } \\
\text { Halajian, Ali; University of Limpopo, Department of Biodiversity } \\
\text { Luus-Powell, Wilmien; University of Limpopo, Department of Biodiversity } \\
\text { Benini, Deborah; University of Bologna, Veterinary Medical Sciences } \\
\text { Tedesco, Perla; University of Bologna, Veterinary Medical Sciences } \\
\text { Kasembele, Gyrhaiss; Universite de Lubumbashi, Unité de recherché en } \\
\text { Biodiversité et Exploitation durable des Zones Humides (BEZHU), Faculté } \\
\text { des Sciences Agronomiques } \\
\text { Fioravanti, Maria; University of Bologna, Dept. Veterinary Medical } \\
\text { Sciences }\end{array}$ \\
\hline Key Words: & $\begin{array}{l}\text { Yellow grub, halzoun, molecular prospecting, hybridization, incomplete } \\
\text { lineage sorting, DNA barcode, heron, catfish }\end{array}$ \\
\hline & \\
\hline
\end{tabular}

\section{SCHOLARONE" Manuscripts}


We appreciate the time and effort the reviewer has spent on our manuscript.

Referee: 1

Comments to the Author

Line 221 Intestinal ceca bifurcation in preacetabular region, forming caecal shoulders before running Is it the caeca that bifurcate? 'Intestinal bifurcation' is a more usual descriptor.

\section{- Changed}

Perhaps 'preacetabular' might confuse some readers as there is no mention of an acetabulum (It is referred to as a ventral sucker in the description and acetabulum in parts of the discussion). It could be replaced by 'in forebody'.

- Although we don't think readers of Parasitology will be confused by the term 'acetabulum', we changed it as the reviewer requests / to 'anterior to the ventral sucker'.

The American spelling 'ceca' and the British spelling 'caecal' are used in the same phrase. Use just one spelling consistently.

- Changed

Line 223. sucker, muscular, trilobed structure well visible - easily visible

- Changed

Line 284. The posterior testis in most descriptions is moon-shaped. The moon is a sphere! Use a more precise descriptor.

- We changed this to 'crescent shaped', the term we use in morphological description 
7

Molecular data show Clinostomoides Dollfus, 1950 is a junior synonym of Clinostomum Leidy, 1856, with redescription of metacercariae of Clinostomum brieni n. comb. (3)

MONICA CAFFARA ${ }^{1 *}$, SEAN A. LOCKE², ALI HALAJIAN ${ }^{3}$, WILMIEN J LUUS-

POWELL ${ }^{3}$, DEBORAH BENINI ${ }^{1}$, PERLA TEDESCO ${ }^{1}$, GYRHAISS KAPEPULA

KASEMBELE $^{4}$, MARIA L. FIORAVANTI ${ }^{1}$

(1)

${ }^{1}$ Department of Veterinary Medical Sciences, Alma Mater Studiorum University of Bologna, Via Tolara di Sopra 50, 40064 Ozzano Emilia (BO), Italy.

2 Department of Biology, University of Puerto Rico, Box 9000, Mayagüez, Puerto Rico 00681-9000.

${ }^{3}$ Department of Biodiversity, University of Limpopo, Private Bag X1106, Sovenga 0727, South Africa.

${ }^{4}$ Unité de recherché en Biodiversité et Exploitation durable des Zones Humides (BEZHU), Faculté des Sciences Agronomiques, Université de Lubumbashi, Haut-Katanga, R.D. Congo.

*Corresponding author: Department of Veterinary Medical Sciences, Alma Mater Studiorum University of Bologna, Via Tolara di Sopra 50, 40064 Ozzano Emilia (BO) E-mail: $\underline{\text { monica.caffara@unibo.it }}$ 


\section{SUMMARY}

The genus Clinostomoides Dollfus, 1950 was erected to accommodate a single worm from Ardea goliath sampled in the Belgian Congo. The specimen was distinguished from other clinostomids by its large size and posterior genitalia. In the following years, metacercariae of Clinostomoides brieni, have been described in Clarias spp. in southern and western Africa. A few authors have referred to Clinostomum brieni, but all such usages appear to be lapsus calami, and the validity of Clinostomoides remains widely accepted. In this study our aim was: position Clinostomoides brieni among the growing clinostomids molecular database, and redescribe the species with emphasis on characters that have emerged as important in recent work. We sequenced two nuclear (partial 18S and ITS) and one mitochondrial marker (partial cytochrome $c$ oxidase I) and studied morphology in metacercariae from hosts and localities likely to harbor the type species (Clarias spp., Democratic Republic of the Congo, South Africa). Phylogenetic analysis shows Clinostomoides brieni belongs within Clinostomum Leidy, 1856. We therefore transfer Clinostomoides brieni to Clinostomum, amend the diagnosis for the genus Clinostomum, and provide a critical analysis of other species in Clinostomoides, all of which we consider species inquirendae, as they rest on comparisons of different developmental stages.

Key words: Yellow grub, halzoun, molecular prospecting, hybridization, incomplete lineage sorting, DNA barcode, heron, catfish 


\section{KEY FINDINGS}

- Genus Clinostomoides Dollfus, 1950 originally distinguished from other clinostomids by large size and posterior genitalia.

- Morphological and molecular study of metacercariae from hosts and localities likely to harbor the type species Clinostomoides brieni (Clarias spp., southern Africa).

- Phylogenetic analysis of three markers (18S, ITS rDNA and CO1 mtDNA) shows Clinostomoides brieni belongs within Clinostomum Leidy, 1856.

- Amended diagnosis for Clinostomum to accommodate inclusion of C. brieni.

- Critical analysis of other species in Clinostomoides, all considered species inquirendae.

\section{INTRODUCTION}

The genus Clinostomoides was erected by Dollfus (1950) to accommodate a single adult collected from the esophagus of Ardea goliath sampled in the Belgian Congo (now Democratic Republic of the Congo - DRC). The type species, C. brieni Dollfus, 1950, was distinguished from Clinostomum based on its large body size $(30 \mathrm{~mm})$, the genital complex in the posterior (rather than middle or across middle and posterior) third of body, and the genital pore located ventral to the posterior testis (rather than lateral to the anterior testis). In the following years, metacercariae of C. brieni were described by Prudhoe (1957) from Clarias lazera collected in Belgian Congo, by Manter and Pritchard (1969) from Clarias sp. from Rwanda, by Fischthal and Thomas (1970) from C. senegalensis in Ghana, by Barson et al. (2008) and by Jansen van Rensburg et al. (2013) from C. gariepinus sampled in Zimbabwe and Botswana, respectively. Outside the African continent, Mirzoeva (1981) described one adult of C. brieni collected from the esophagus of Ardea purpurea in Azerbaijan, and metacercariae of C. brieni were also reported in the Philippines (Arthur and Lumanlan-Mayo, 1997). 
Additional species of Clinostomoides have been described in Central India, the first being $C$. dollfusi Agarwal 1958, followed by C. ophicephali (Tubangui and Masiluñgan, 1935) Agarwal 1958 (transferred from genus Clinostomum), C. chauhani Pandey 1971, C. rai Rai 1970, C. meerutensis Pandey and Tyagi 1986, C. pandeyii Singh and Sharma 1994, and C. baughi Pandey 1998. However, all were erected based either on comparisons among these regional species or with the earliest species in the region, C. dollfusi. Most importantly, all, including $C$. dollfusi, were based on metacercariae. This is problematic because in erecting $C$. dollfusi, Agarwal (1958) compared metacercariae with the adult described by Dollfus (1950), not with metacercariae described by Prudhoe (1957). Manter and Pritchard (1969) synonymized $C$. dollfusi with $C$. brieni, and their doubts about the morphological characters used to erect the junior species were confirmed by Fischthal and Thomas (1970). However, subsequent work in India has not taken the latter studies into account and continues to treat as valid C. dollfusi and other species erected in comparison to it (e.g. Pandey and Agrawal, 2013). Finally, the species described by Dollfus has occasionally been reported as Clinostomum brieni, in lapsus calami. Prudhoe (1957) and Douellou (1992) used both "Clinostomum brieni" and "Clinostomoides brieni" as names for the same species, and Lio-Po et al (1983) listed "Clinostomum brieni," but without taxonomic comment or support. Other than these isolated cases, the genus Clinostomoides and its type species Clinostomoides brieni are widely considered valid (e.g., Kanev et al. 2002).

A combination of molecular and morphological approaches is a useful way to resolve situations like this, as has already been shown in other clinostomids, i.e., Clinostomum Leidy, 1856 (Caffara et al. 2011; Sereno-Uribe et al. 2013), Euclinostomum Travassos, 1928 (Senapin et al. 2014; Caffara et al. 2016), Odhneriotrema Travassos, 1928 (Woodyard et al. 2017) and Ithyoclinostomum Witenberg, 1925 (Briosio-Aguilar et al. 2018). However, few DNA sequences from Clinostomoides are currently available for comparison. Athokpam et al 
(2014) provided rDNA sequences from $C$. brieni, but without supporting morphological information. Moreover, the identification of $C$. brieni by these authors was questioned by Brioso-Aguilar et al (2018) because of the close relationship of its 28S sequence to data from Clinostomum. It is also relevant that the material sequenced by Athokpam et al (2014) was from Heteropneustes in Northeastern India, rather than the region or hosts (central and southern Africa, Clarias, Ardea) where the genus originated and is better known.

The aim of this work was to provide a redescription of Clinostomoides brieni metacercariae based on morphological and molecular analyses, following Matthews and Cribb (1998), and to provide an updated critical analysis of previously described species. To this end, we collected in localities and hosts in which we were likely to encounter the same species as Dollfus (1950) and Prudhoe (1957), with the aim of characterizing the type species. Our results led us to transfer Clinostomoides brieni to Clinostomum and to consider species of Clinostomoides from India as species inquirendae.

\section{MATERIALS AND METHODS}

Two metacercariae of Clinostomoides sp. were collected from Clarias gariepinus sampled at Phalaborwa barrage, Limpopo province (South Africa) and four from C. ngamensis sampled in the Democratic Republic of the Congo (1 from Lake Tshangalele, Kapolowe Mission and 3 from Kiswishi River near Futuka Farm). All were recovered from the body cavity, cleaned in saline and preserved in $70 \%$ ethanol.

Total lengths of metacercariae were measured before cutting a small piece of the posterior end for molecular analyses. Morphometrics of hologenophores (sensu Pleijel et al. 2008) were taken after clarification with Amman's lactophenol and staining by Malzacher's method (Pritchard and Kruse, 1982). Line drawings were made with the aid of a drawing tube, and measurements are given in micrometers following Matthews and Cribb (1998). DNA was 
extracted from hologenophore subsamples using a PureLink Genomic DNA Kit (Invitrogen) following the manufacturer's protocol. Amplification of $18 \mathrm{~S}$ and Internal transcribed Spacer 1-5.8S-Internal Transcribed Spacer 2 (ITS) rDNA employed protocols and primers of Gustinelli et al. (2010), cytochrome $c$ oxidase I (CO1) mtDNA those of Moszczynska et al. (2009).

Amplified products were resolved on a 1\% agarose gel stained with SYBR Safe DNA Gel Stain in $0.5 \times$ TBE (Molecular Probes - Life Technologies). For sequencing of 18S, ITS and CO1, bands were excised and purified by NucleoSpin Gel and PCR Cleanup (MackereyNagel) and sequenced with an ABI 3730 DNA analyser at StarSEQ GmbH (Mainz, Germany). Contigs were assembled with Vector NTI AdvanceTM 11 software (Invitrogen) and sequences are published in GenBank under the following accession numbers: MH606186-90 (18S), MH238412-16 (ITS) and MH253044-48 (CO1). Pairwise p-distances and models of nucleotide evolution (BIC) were calculated using MEGA 6.06 (Tamura et al. 2013). For trees constructed with Bayesian Inference, in MrBayes 3.2.6 (Ronquist et al. 2012), nst=2+G was used for ITS and 18S, and GTR+G+I was used for CO1. The K2P+G-model was used for Maximum Likelihood analysis in MEGA of $18 \mathrm{~S}$ and ITS rDNA while $\mathrm{GTR}+\mathrm{G}+\mathrm{I}$ was used for $\mathrm{ML}$ analysis of $\mathrm{CO} 1 \mathrm{mtDNA}$.

The newly generated sequences of $18 \mathrm{~S}$, ITS and CO1 were aligned along with one or two representative sequences of Clinostomum species (C. complanatum, C. cutaneum, $C$. phalacrocoracis, C. tilapiae, C. philippinensis, C. marginatum, C. tataxumui, C. album, C. poteae, C. heluans, C. attenuatum, C. detruncatum, C. arquus, C. caffarae, C. cichlidorum) plus undescribed or unidentified species of Clinostomum (Locke et al. 2015; Caffara et al. 2017). Euclinostomum heterostomum (ITS: KP721422, CO1: KP721404), Odhneriotrema incommodum (ITS: MF766000, CO1: MF766003) and Ithyoclinostomum (ITS: MH159753, CO1: MH159752) were used as outgroup for the subfamily Clinostomatinae, while 
Tylodelphys immer (18S and ITS: MH521252; CO1: MH536513), Cyathocotyle prussica (18S and ITS: MH521249; CO1: MH536510), Schistosoma mansoni (18S: U65657; ITS: AY446082) as outgroup for Clinostomidae. All codon positions in the CO1 alignment were used in the analysis because of lack of evidence of nucleotide saturation (Iss $=0.237$, Iss.c=0.697, $\mathrm{df}=472, \mathrm{P}=0$, Xia et al. 2003; Xia and Lemey, 2009).

\section{RESULTS}

Among five $18 \mathrm{~S}$ rDNA sequences $1826-1877$ bp in length obtained from African samples of C. brieni in the present study, there were four variable sites, all transitions, i.e. mean divergence $0.1 \%$, range $0-0.2 \%$. All variation was in two sequences from South Africa; three 18S sequences from Congo were identical. An 18S sequence (KF781300, 1907 bp) of Athokpam et al. (2014) from C. brieni from Heteropneustes fossilis in Manipur differed at 32 positions $(1.7 \%)$ from another $18 \mathrm{~S}$ sequence by the same authors (KF811009, $1859 \mathrm{bp})$ from the same host in Meghalaya (the latter sequence is not mentioned in the paper of Athokpam et al. 2014). Variation in $18 \mathrm{~S}$ between the five African C. brieni sequences and the two Indian isolates averaged $1.4 \%$ (range $0.5-2.6 \%$ ). Phylogenetic analysis showed that $18 \mathrm{~S}$ sequences from Indian and African C. brieni form a well-supported clade nested within Clinostomum species. The Clinostomum + C. brieni clade is also well supported, and comparatively deeply divergent from Euclinostomum. Variation among 18S sequences of Clinostomum spp. averaged $0.9 \%$ (range $0.2-1.5 \%$ ) and in the Clinostomum + C. brieni clade, $18 \mathrm{~S}$ variation averaged $1.1 \%$ (range $0-3.6 \%$ ). All the highest divergence values $(\geq 1.8 \%)$ in the latter clade were associated with the unpublished $C$. brieni sequence KF811009. Variation between Euclinostomum and members of the Clinostomum + C. brieni clade averaged 2.8\% (range 2.4$5.0 \%)$ 
172 The five ITS rDNA sequences $1005-1028$ bp in length from African C. brieni were identical 173 to each other and to the 300-bp ITS2 sequence of C. brieni (KF781298) of Athokpam et al. 174 (2014). The ITS of C. brieni varied by a mean of 5.7\% (range 4.7-7.1\%) from species of

Clinostomum. Variation in ITS among species of Clinostomum s.s. was of similar magnitude: mean $4.9 \%$ (range $0.1-8.6 \%$ ). In contrast, ITS variation among members of the genera Euclinostomum, Odhneriotrema, and Clinostomum + Clinostomoides averaged 15.2\% (range $13.9-16.3 \%)$.

The CO1 sequences of four specimens of $C$. brieni were identical but that of one specimen (MH253045, from C. gariepinus in South Africa) differed by 11\% from the other four. This specimen did not differ morphologically from the other five C. brieni examined, and its $18 \mathrm{~S}$ (MH606187) and ITS (MH238413) sequences were not similarly divergent (Figs 1, 2). The CO1 of this specimen differed by $0.2 \%$ from Clinostomum morphotype 3 (KY865667, from the Amphilius uranoscopus in South Africa). The DNA from this specimen was amplified and sequenced an additional four times with the same results. The BI and ML trees were based on a 473 bp CO1 alignment and had little statistical support at deeper nodes, but both showed $C$. brieni within Clinostomum. The C. brieni specimen MH253045 grouped with Clinostomum sp. morphotype 3, while the other four C. brieni sequences form a monophyletic clade within the Old-World clade of Clinostomum species. The four monophyletic C. brieni sequences differ by mean $15.3 \%$ (range $13-19.5 \%$ ) from other Clinostomum species. Interspecific CO1 variation in Clinostomum is similar, with mean $16.3 \%$ (range $3.5-22.1 \%$ ). The mean intergeneric $\mathrm{CO} 1$ distances between members of Odhneriotrema, Clinostomoides + Clinostomum, Euclinostomum and Ithyoclinostomum is 19.8\% (range 17.3-23.5\%).

Analyses of three molecular markers indicate Clinostomoides should be regarded as junior synonym of Clinostomum, as amended below. Tree topologies (Figs. 1-3) show relatively deep divergence between Odhneriotrema, Euclinostomum and Clinostomum whereas 
Clinostomoides falls within a clade of Clinostomum species. Genetic distances between $C$. brieni and Clinostomum species are comparable to those within Clinostomum s.s. and inferior to distances among other clinostomid genera.

\section{Clinostomum Leidy, 1856}

(Synonym Clinostomoides Dollfus, 1950)

Family Clinostomidae Lühe, 1901

\section{Subfamily Clinostominae Lühe, 1901}

Body medium to very large, linguiform, stout, convex dorsally and concave ventrally. Tegument smooth or with spines. Oral sucker may or may not be surrounded by collar-like fold when retracted. Ventral sucker muscular, well developed, always larger than oral sucker. Caeca long, simple, with more or less sinuous wall, particularly in anterior half of body, but lacking lateral branches or diverticula. Testes smooth or irregular in shape, in posterior half of body. Ovary intertesticular, to right of medial line. Vitelline follicles in lateral fields anteriorly, from level of intestinal bifurcation or ventral sucker to posterior extremity, may remain lateral and extracaecal or become confluent posterior to genital complex. Uterus intercaecal, extending from Mehlis' gland to fill part of total distance to ventral sucker. Genital pore anterior, lateral or posterior to testicular-ovary complex. Cosmopolitan. Type species Clinostomum complanatum (Rudolphi, 1819).

Morphological Description of Clinostomum brieni (Dollfus, 1950) n. comb. (Fig. 4, Table 1) (based on 5 hologenophores and 1 paragenophore)

(Synonym Clinostomoides brieni Dollfus, 1950)

Body regularly elongated, narrow, tongue-shaped. Oral sucker small, with indistinct marginal limits. Pre-pharynx cup-shaped elongated, thick, muscular. Pharynx visible, muscular. 
Intestinal bifurcation anterior to ventral sucker, forming caecal shoulders before running laterally to ventral sucker to posterior end of body. Ventral sucker robust, larger than oral sucker, muscular, trilobed structure easily visible. Caeca provided with small lateral pockets becoming more digitated posteriorly to ventral sucker. Whole genital complex in posterior part of posterior third of body. Testes two, tandem, intercaecal, transversely elongated. Anterior testis bow-tie shaped. Posterior testis Y- to crescent shaped with anterior margin concave. Cirrus sac comma-shaped, thick walled, intertesticular dextral, from right posterior margin of anterior testis to anterior margin of posterior testis, genital pore opening in concave margin of posterior testis. Ovary small, intertesticular dextrally to cirrus sac, close to right margin of posterior testis.

Uteroduct emerging from ootype complex runs around left margin of anterior testis, ascending sinistrally with some undulation to slightly above metraterm before looping posteriorly on itself entering directly into the proximal part of uteroduct and opening into uterine sac. Uterine sac median elongate narrow, tip reaching the posterior part of middle third of body. Tegument armed with spines $(8-11 \mu \mathrm{m})$ from posterior part of oral sucker to posterior end of body. Excretory bladder Y-shaped, postcaecal, arms extending anteriorly in extracaecal position. Excretory pore terminal.

\section{DISCUSSION}

Our original aim was redescribe metacercariae of Clinostomoides brieni and assess the relationship of the species with other clinostomids using DNA. Unexpectedly, the molecular data strongly indicate the species belongs within Clinostomum, which led us to amend the diagnosis of the genus to accommodate Clinostomum brieni n. comb. The genus

Clinostomoides was limited to Afrotropic and Indo-Malayan regions, and most reports are from Clarias or Heteropneustes, which are closely related siluriform genera occurring in the 
same regions (Hardman, 2005; Kushwaha et al. 2015; Froese and Pauly, 2018). The phylogenetic association of C. brieni with a clade of Old-World Clinostomum species (Figs 13 ) is consistent with a biogeographic pattern that continues to be observed as data accumulate from more species of Clinostomum (Locke et al. 2015; Pérez-Ponce de León et al. 2016; Rosser et al. 2018), which adds further evidence that C. brieni belongs to Clinostomum.

One specimen we collected was morphologically indistinguishable and shared identical rDNA sequences with other $C$. brieni, but its CO1 (MH253045) was highly divergent, and nearly identical to Clinostomum morphotype 3, which Caffara et al. (2017) obtained from mochokid and amphiliid catfishes in South Africa. We believe this can be most plausibly explained by hybridization. Both C. brieni and Clinostomum morphotype 3 infect siluriform second intermediate hosts in the same region, which are preyed upon by local ardeid definitive hosts, including the type host of C. brieni, A. goliath (Mock and Mock, 1980). Other than this particular specimen, C. brieni and Clinostomum morphotype 3 appear to be distantly related (Figs. 1,2). This argues against another possible explanation for mitochondrial haplotype sharing between C. brieni and Clinostomum morphotype 3, incomplete sorting among recently separated species. In any event, when viewed together with the highly distinctive morphology of $C$. brieni, both hybridization and incomplete lineage sorting suggest species belonging to a single genus, which supports our main taxonomic conclusion.

The most distinctive characters of Clinostomoides were the size of the adult (30 $\mathrm{mm})$ described in A. goliath by Dollfus (1950), the extremely posterior position of the genital complex, and the position of the cirrus sac and genital pore within the genital complex, characters considered also in regional descriptions of metacercariae (Prudhoe, 1957; Manter and Pritchard, 1969; Fischthal and Thomas, 1970; van Rensburg et al. 2013). The most obvious distinction of Clinostomoides, its large size, is noteworthy in that the adult is known only from the largest of ardeids, A. goliath (Mock and Mock, 1980). In light of the molecular 
271 evidence that Clinostomoides belongs within Clinostomum, the other characters may be considered as size-related allometric changes.

The clinostomid metacercariae we collected from Clarias species in South Africa and

Democratic Republic of the Congo were morphologically consistent with previous descriptions of C. brieni in the same host and region (Prudhoe, 1957; Manter and Pritchard, 1969; Fischthal and Thomas, 1970; van Rensburg et al. 2013). The only inconsistency was the pharyngeal morphology. Fischthal and Thomas (1970) reported a thick-walled, muscular pre-pharynx and very muscular pharynx (as observed in our specimens), while Prudhoe (1957) reported the pharynx absent, Manter and Pritchard (1969) did not mention it, and van Rensburg et al. (2013) reported a short pre-pharynx and muscular pharynx. In our opinion, these structures are probably always present but not always visible.

As the genital complex provides reliable features for discriminating species of Clinostomum (i.e. Caffara et al. 2017, Sereno-Uribe et al. 2018, see Table 2), it can also shed light on prior records of Clinostomum brieni. The posterior testis in most descriptions is crescent-shaped, and showed this form in two of six subjects we examined, but in four worms the posterior testis was Y-shaped, as also reported by Fischthal and Thomas (1970). In metacercariae of Clinostomum, testes are more digitated than in pre-adults/adults (Ukoli, 1966). The only description of the adult of $C$. brieni is that of Dollfus (1950), who reported testes similar to those later described in metacercariae, except for small marginal lobules in the adult organs. Thus, in this species of Clinostomum, developmental variation in the morphology of the testicular margin appears to be reversed (going from smooth to more digitated), although data 292 are needed from additional adults to confirm this. The cirrus pouch (CP) in C. brieni is well developed and lies between the testes, at a variable distance from the posterior border of the anterior testis and touching the concave part of the posterior testis where the genital pore opens. This pattern has been observed in all previous descriptions of C. brieni except that of 
Fischthal and Thomas (1970), in which the CP did not touch the posterior testis. Finally, in all metacercarial descriptions the uteroduct forms a similar loop devoid of eggs, which becomes filled with eggs in the adult (Dollfus, 1950).

Molecular data indicate a single species (albeit with potential capacity to hybridize) of Clinostomum brieni among samples spanning approximately $1500 \mathrm{~km}$ of the known geographic range of this species, including the type region. Morphological differences among our specimens and those of prior regional accounts (Dollfus, 1950; Prudhoe, 1957; Manter and Pritchard, 1969; Jansen van Rensburg et al. 2013) therefore likely represent intraspecific variation. This can provide a useful perspective for considering species of Clinostomoides described from the Indian subcontinent, the first of which was C. dollfusi, which Agarwal (1958) described from metacercariae from Clarias sp. and Heteropneustes (=Saccobranchus) sp. collected in Jabalpur. Agarwal (1958) emphasized body length (7.8-9.8 $\mathrm{mm}$ in the Indian metacercariae $v s$ the $30 \mathrm{~mm}$ in adult holotype of $C$. brieni), the absence of lateral sacculations of the uterus, and distance between suckers. However, all these characters are in fact typical of metacercariae of C. brieni (Manter and Pritchard, 1969; Fischthal and Thomas, 1970; Van Rensburg et al. 2013; present study), if not of the larger adult holotype. All other species of Clinostomoides in this region are from Heteropneustes. Clinostomoides chauhani Pandey, 1971, was described from the body cavity and viscera of $H$. fossilis collected in Lucknow, based on comparison with $C$. dollfusi and $C$. ophicephali, which were both synonymized with C. brieni by Manter and Pritchard (1969) and Fischthal and Thomas (1970). The species $C$. chauhani is said to possess an aspinose body but spinose cuticle (Pandey and Agrawal, 2013). Clinostomoides rai was proposed by Rai (1970) (later revised by Pandey, 1974) for metacercariae from the intestine of Clarias batrachus collected in Mathura, on the basis of distance between suckers and limbs of uterus (Pandey and Agrawal, 2013). However, Pandey and Agrawal (2013) appear to have mistranscribed morphological values (i.e. acetabulum 
$1.16 \times 0.78 \mathrm{~mm} v s$ acetabulum at distance of $1.16 \mathrm{~mm}$ behind anterior end of body and 0.78 $\mathrm{mm}$ in diameter) and host tissues (muscle $v s$ intestine) recorded by Rai (1970).

Clinostomoides meerutensis Pandey and Tyagi, 1986 and C. pandeyii Singh and Sharma, 1994, were both created for metacercariae from the body surface of $H$. fossilis in Meerut based on a spinose tegument and ovary opposite to cirrus sac. Pandey and Kiran (2002) synonymized C. rai, C. meerutensis and C. pandeyii with C. dollfusi. Clinostomoides baughi Pandey, 1998 was described from metacercariae in skin near the operculum of $H$. fossilis in Lucknow, based only on comparisons with the species of Indian Clinostomoides mentioned above. In the descriptions of C. meerutensis, C. pandeyii and C. baughi, the ovary is described as opposite to the cirrus sac. However, to our knowledge the ovary in the genus Clinostomoides and/or Clinostomum is always on the same side as the cirrus pouch. Line drawings in Pandey and Agrawal (2013) appear to show specimens of the latter three species transposed, with the uteroduct in the right side of the body.

In our opinion, these species of Clinostomoides (C. dollfusi, C. rai, C. chauhani, $C$. meerutensis, C. pandeyii, C baughi) described from India are species inquirendae because the morphological basis of each may be an artifact of development, beginning with the comparison of larval $C$. dollfusi with adult $C$. brieni and cascading through later descriptions. The characters considered in these studies vary with parasite development and may also be influenced by fixation and mounting (Manter and Pritchard, 1969; Fischthal and Thomas, 1970). Until such species can be verified through morphological comparisons at equivalent stages of development, preferably with detailed accounts of the genital complex and with supporting molecular data, we consider only Clinostomum brieni to be valid. Essentially, this view follows Manter and Pritchard (1969) and Fischthal and Thomas (1970). Further work may reveal additional species of Clinostomum with the Clinostomoides-morphotype on the Indian subcontinent or elsewhere, but currently this is supported with neither molecular (Figs. 
1,2) nor morphological data. Connectivity between Indian and African populations of $C$.

347 brieni could be maintained by species of Ardea which occur in both regions (e.g., A. cinerea,

348 A. purpurea, A. goliath, BirdLife International, 2018).

349

350

351

352

353

354

355

356

357

358

359

360

361

362

\section{ACKNOWLEDGEMENTS}

The authors are grateful for the support of Professor A. Chocha Manda (Université de Lubumbashi, R.D. Congo) and for constructive suggestions made by two anonymous reviewers.

\section{FINANCIAL SUPPORT}

Part of the research done in South Africa by AH was supported by the South African Research Chairs Initiative of the Department of Science and Technology and National Research Foundation (NRF) of South Africa (Grant No 101054). Any opinion, finding and conclusion or recommendation expressed in this material is that of the author(s) and the NRF does not accept any liability in this regard. SL was supported by the Puerto Rico Science Technology \& Research Trust. MC, DB, TP and MLF received no specific grant from any funding agency, commercial or not-for-profit sectors. 


\section{REFERENCE}

364

365

Agarwal SM (1958) Studies on the metacercaria Clinostomoides dollfusi n. sp. (Trematoda:

Clinostomatidae) from siluroid fishes. Indian Journal of Helminthology 10, 13-18.

Arthur JR and Lumanlan-Mayo S (1997) Checklist of the parasites of fishes of the Philippines. FAO Fisheries Technical Paper, 369, 1-102.

Athokpam VD, Jyrwa DB, and Tandon V (2014) Utilizing ribosomal DNA gene marker regions to characterize the metacercariae (Trematoda: Digenea) parasitizing piscine intermediate hosts in Manipur, Northeast India. Journal of Parasitic Diseases 40, 330-338.

Barson M, Bray RA, Ollevier F and Huyse T (2008) Taxonomy and faunistics of the helminth parasites of Clarias gariepinus (Burchell, 1822), and Oreochromis mossambicus (Peters, 1852) from temporary pans and pools in the Save-Runde River Floodplain, Zimbabwe. Comparative Parasitology 75, 228-240.

BirdLife International (2018) IUCN Red List for Birds. Downloaded from http://www.birdlife.org on 05/08/2018.

Briosio-Aguilar R, García-Varela M, Hernández-Mena DI, Rubio-Godoy M and PérezPonce de León G (2018) Morphological and molecular characterization of an enigmatic clinostomid trematode (Digenea: Clinostomidae) parasitic as metacercariae in the body cavity of freshwater fishes (Cichlidae) across Middle America. Journal of Helminthology in press, DOI: $10.1017 / \mathrm{S} 0022149 \mathrm{X} 18000445$.

\section{Caffara M, Locke SA, Gustinelli A, Marcogliese DJ and Fioravanti ML (2011)}

Morphological and molecular differentiation of Clinostomum complanatum and Clinostomum marginatum (Digenea: Clinostomidae) metacercariae and adults. Journal of Parasitology 97, 884-891. 


\section{Caffara M, Locke SA, Cristanini C, Davidovich N, Markovich MP and Fioravanti ML}

(2016) A combined morphometric and molecular approach to identifying metacercariae of Euclinostomum heterostomum (Digenea: Clinostomidae). Journal of Parasitology 102, 239248.

\section{Caffara M, Locke SA, Echi PC, Halajian A, Benini D, Luus-Powell WJ, Tavakol S and}

Fioravanti ML (2017) A morphological and molecular study of Clinostomid metacercariae from African fish with a redescription of Clinostomum tilapiae. Parasitology 144, 1519-1529.

Dollfus RP (1950) Trématodes récoltés au Congo Belge, par le Professeur Paul Brien. Annales Du Musée Du Congo Belge (Zoologie) 1, 1-136.

Douellou L (1992). A survey of fish parasites in Lake Kariba, Zimbabwe (1989-1992) final report. University of Zimbabwe, Lake Kariba Research Station ULKRS Bulletin 1/92 1, 1-72.

Fischthal JH and Thomas JD (1970) Some metacercariae of digenetic trematodes in fishes from Nungua Lake, Ghana. Anales del Instituto de Biología Universidad Nacional Autonoma de México Serie Zoología 1, 73-80.

Froese R and Pauly D Editors. (2000) FishBase 2000: concepts, design and data sources. ICLARM, Los Baños, Laguna, Philippines. 344 p.

\section{Gustinelli A, Caffara M, Florio D, Otachi EO, Wathuta EM and Fioravanti ML (2010)}

First description of the adult stage of Clinostomum cutaneum Paperna, 1964 (Digenea:

Clinostomidae) from grey herons Ardea cinerea L. and a redescription of the metacercaria from the Nile tilapia Oreochromis niloticus niloticus (L.) in Kenya. Systematic Parasitology 76, 39-51.

Hardman M (2005) The phylogenetic relationships among non-diplomystid catfishes as inferred from mitochondrial cytochrome $b$ sequences; the search for the ictalurid sister taxon (Otophysi: Siluriformes). Molecular Phylogenetics and Evolution 37, 700-720. 
Jansen van Rensburg C, van As JG and King PH (2013) New records of digenean parasites of Clarias gariepinus (Pisces: Clariidae) from the Okavango Delta, Botswana, with description of Thaparotrema botswanensis sp. n. (Plathelminthes: Trematoda). African Invertebrates 54, 431-446.

Kanev I, Radev V and Fried B (2002) Family Clinostomidae Lühe, 1901. In Gibson DI, Jones A and Bray R (eds). Keys to the Trematoda Vol. 1). London, U.K: CAB International and the Natural History Museum, pp. 113-120.

\section{Kushwaha B, Kumar R, Agarwal S, Pandey M, Nagpure NS, Singh M, Srivastava S,} Joshi CG, Das P, Sahoo L and Jayasankar P (2015) Assembly and variation analyses of Clarias batrachus mitogenome retrieved from WGS data and its phylogenetic relationship with other catfishes. Meta Gene 5, 105-114.

Lio-Po G D, Pascual JP and Santos JG (1983) Philippines. Paper presented at the Fish quarantine and fish diseases in Southeast Asia. Report of a workshop held in Jakarta, Indonesia, 7-10 December 1982, Jakarta, 35-43

Locke SA, Caffara M, Marcogliese DJ and Fioravanti ML (2015) A large-scale molecular survey of Clinostomum (Digenea: Clinostomidae). Zoologica Scripta 44, 203-217.

Manter HW and Pritchard MH (1969) Some digenetic trematodes of Central Africa chiefly from fishes. Revue de Zoologie et de Botanique Africaines 80, 51-61.

Matthews D and Cribb TH (1998) Digenetic trematodes of the genus Clinostomum Leidy, 1856 (Digenea: Clinostomidae) from birds of Queensland, Australia, including C. wilsoni from Egretta intermedia. Systematic Parasitology 39, 199-208.

Mirzoeva SS (1981) On the finding of Clinostomoides brieni Dollfus, 1950 (Trematoda: Clinostomatidae) in Azerbaijan. Parazitologiya 15, 288-290 (In Russian). 
433

434

435

436

437

438

439

440

441

442

443

444

445

446

447

448

449

450

451

452

453

454

Mock DW and Mock KC (1980) Feeding behavior and ecology of the goliath heron. The Auk 97, 433-448.

Moszczynska A, Locke SA, McLaughlin JD, Marcogliese DJ and Crease TJ (2009)

Development of primers for the mitochondrial cytochrome $c$ oxidase I gene in digenetic trematodes illustrates the challenge of barcoding parasitic helminths. Molecular Ecology Resources 9, 75-82.

Pandey KC (1971) Studies on clinostome metacercaria VIII. On a rare Clinostome metacercaria from Heteropneustes fossilis (Bloch). Proceedings of the Indian Academy of Science 43, 1-3.

Pandey N (1998) Contribution to our Knowledge of Some Parasites (Monogeneans and Digeneans) of Fishes. PhD thesis Department of Zoology Lucknow University, Lucknow, India. Retrieved from http://ir.amu.ac.in/2333/1/T\%205321.pdf (accessed 22 May 2018).

Pandey KC and Tyagi V (1986) On a new species of the genus Clinostomoides Dollfus, 1950 from Heteropneustes fossilis (Bloch). Indian Journal of Helminthology 3, 83-86.

Pandey KC and Kiran (2002) Further observations on Clinostomoides dollfusi Agarwal, 1958. Indian Journal of Helminthology 20, 7-10.

Pandey KC and Agrawal N (2013) Metacercarial Fauna of India, Record of Zoological Survey of India. Occasional Paper No., 349: 1-310, Published by Director, Zoological Survey of India, Kolkata.

Pérez-Ponce de León G, García-Varela M, Pinacho-Pinacho CD, Sereno-Uribe AL and Poulin R (2016) Species delimitation in trematodes using DNA sequences: Middle-American Clinostomum as a case study. Parasitology 143, 1773-1789. 
Pleijel F, Jondelius U, Norlinder E, Nygren A, Oxelman B, Schander C, Sundberg P and Thollesson M (2008) Phylogenies without roots? A plea for the use of vouchers in molecular phylogenetic studies. Molecular Phylogenetics Evolution 48, 369-371.

Pritchard MH and Kruse G (1982) The Collection and Preservation of Animal Parasites. University of Nebraska Press, Lincoln, Nebraska.

Prudhoe S (1957) Exploration du Parc National de l’Upemba. Mission G. F. de Witte (19461949). Trematoda. Institute Parc National Congo Belge, Bruxelles, 48, 1-28.

Rai P (1970) On the clinostomatid metacercaria in some of our edible fishes and remarks on the pathological significance. Indian Journal of Animal Sciences 40, 189-198.

Ronquist F, Teslenko M, Van Der Mark P, Ayres DL, Darling A, Höhna S, Larget B, Liu L, Suchard MA and Huelsenbeck JP (2012) MrBayes 3.2: efficient Bayesian phylogenetic inference and model choice across a large model space. Systematic Biology $\mathbf{6 1}$, $539-542$.

Rosser TG, Baumgartner WA, Alberson NR, Noto TW, Woodyard ET, King DT, Wise DJ and Griffin MJ (2018) Clinostomum poteae n. sp. (Digenea: Clinostomidae), in the trachea of a double-crested cormorant Phalacrocorax auritus Lesson, 1831 and molecular data linking the lifecycle stages of Clinostomum album Rosser, Alberson, Woodyard, Cunningham, Pote \& Griffin, 2017 in Mississippi, USA. Systematic Parasitology 95, 543566.

Senapin S, Phiwsaiya K, Laosinchai P, Kowasupat C, Ruenwongsa P and Panijpan B (2014) Phylogenetic analysis of parasitic trematodes of the genus Euclinostomum found in Trichopsis and Betta fish. Journal of Parasitology 100, 368-371.

Sereno-Uribe AL, Pinacho-Pinacho CD, García-Varela M and Pérez-Ponce de León G (2013) Using mitochondrial and ribosomal DNA sequences to test the taxonomic validity of 
Clinostomum complanatum Rudolphi, 1814 in fish-eating birds and freshwater fishes in

Mexico, with the description of a new species. Parasitology Research 112, 2855-2870.

\section{Sereno-Uribe AL, García-Varela M, Pinacho-Pinacho CD and Pérez-Ponce de León G}

(2018) Three new species of Clinostomum Leidy, 1856 (Trematoda) from Middle American fish-eating birds. Parasitology Research 117, 2171-2185.

Singh HS and Sharma B (1994) Clinostomoides pandeyii n. sp., a rare Clinostome metacercaria from Heteropneustes fossilis (Bloch). Uttar Pradesh Journal of Zoology 14, 9193.

Tamura K, Stecher G, Peterson D, Filipski A and Kumar S (2013) MEGA6: Molecular Evolutionary Genetics Analysis version 6.0. Molecular Biology and Evolution 30, 27252729.

Tubangui MA and Masiluñgan VA (1935) Trematode parasites of Philippine vertebrates, VII. Additional records of new species. Philippine Journal of Science 58, 435-446.

Ukoli FM (1966) On Clinostomum tilapiae n. sp., and C. phalacrocoracis Dubois, 1931 from Ghana, and a discussion of the systematics of the genus Clinostomum Leidy, 1856. Journal of Helminthology 40,187-214.

Woodyard ET, Rosser TG and Rush SA (2017) Alligator wrestling: morphological, molecular, and phylogenetic data on Odhneriotrema incommodum (Leidy, 1856) (Digenea: Clinostomidae) from Alligator mississippiensis Daudin, 1801 in Mississippi, USA. Parasitology Research 116, 2981-2993.

Xia X and Lemey P (2009) Assessing substitution saturation with DAMBE. In Lemey P, Salemi M and Vandamme AM (eds). The Phylogenetic Handbook: A Practical Approach to DNA and Protein Phylogeny. 2nd edition Cambridge University Press. pp. 615-630. 
502 Xia X, Xie Z, Salemi M, Chen L and Wang Y (2003) An index of substitution saturation 503 and its application. Molecular Phylogenetics and Evolution 26, 1-7. 
505 Fig. 1. Evolutionary history inferred using Bayesian Inference (nst=2+G) from 18S rDNA of

506 Clinostomum brieni $\mathrm{n}$. comb. generated in this study (in bold) with data from other studies (22

507 nucleotide sequences, 1663 positions). Nodes are labelled with posterior probability in

508 Bayesian Inference analysis and, after the slash, percent of bootstrap support in 1000

509 replicates in Maximum Likelihood. SA=South Africa, DRC=Democratic Republic of the

510 Congo.

511 Fig. 2. Evolutionary history inferred using the Bayesian Inference analysis $(\mathrm{nst}=2+\mathrm{G})$ from

512 ITS rDNA of Clinostomum brieni $\mathrm{n}$. comb. generated in this study (in bold) with data from

513 other studies (36 nucleotide sequences, 575 positions). Nodes are labelled posterior

514 probability and, after the slash, with percent of bootstrap support in 1000 replicates in

515 Maximum Likelihood. SA=South Africa, DRC=Democratic Republic of the Congo.

516 Fig. 3. Evolutionary history inferred in Bayesian Inference analysis (GTR+G+I) from CO1

517 mtDNA of Clinostomum brieni $\mathrm{n}$. comb. generated in this study (in bold) with data from other

518 studies (37 nucleotide sequences, 473 positions). Nodes are labelled with posterior probability

519 and, after the slash, percent of bootstrap support in 1000 replicates in separate Maximum

520 Likelihood analysis; an asterisk indicates a clade that was not recovered with Maximum

521 Likelihood. SA=South Africa, DRC=Democratic Republic of the Congo.

522 Fig. 4. Line drawing of metacercaria of Clinostomum brieni $\mathrm{n}$. comb. Scale bar $=1000 \mu \mathrm{m}$. 


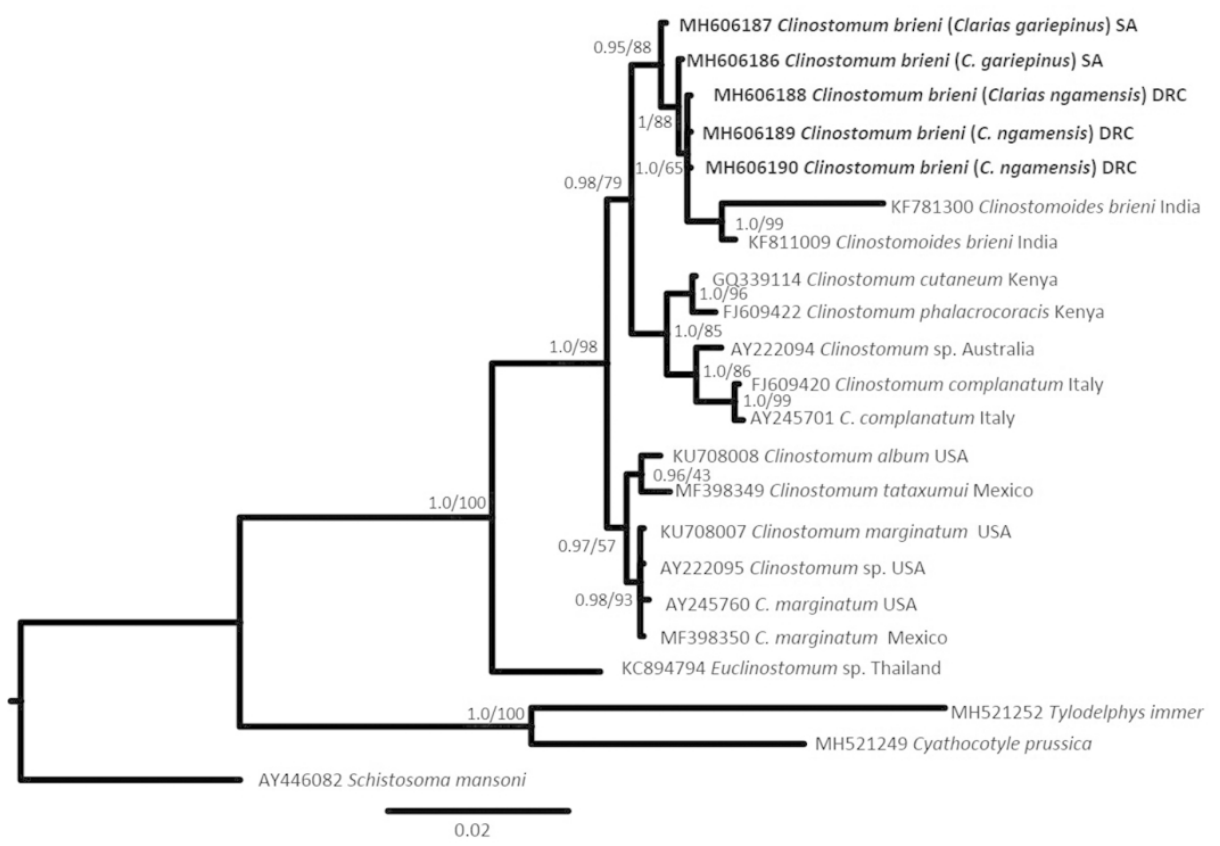

Fig. 1. Evolutionary history inferred using Bayesian Inference ( $n s t=2+G$ ) from 185 rDNA of Clinostomum brieni $n$. comb. generated in this study (in bold) with data from other studies (22 nucleotide sequences, 1663 positions). Nodes are labelled with posterior probability in Bayesian Inference analysis and, after the slash, percent of bootstrap support in 1000 replicates in Maximum Likelihood. SA=South Africa, $\mathrm{DRC}=$ Democratic Republic of the Congo. 


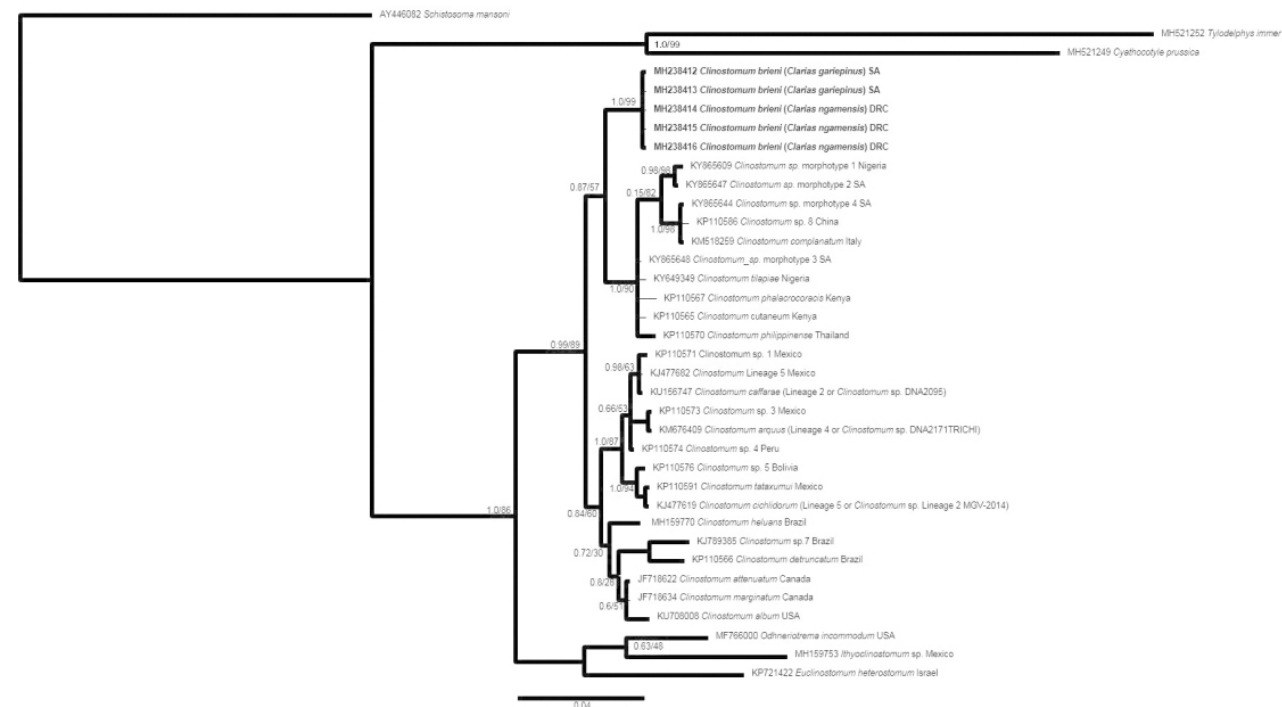

Fig. 2. Evolutionary history inferred using the Bayesian Inference analysis (nst=2+G) from ITS rDNA of Clinostomum brieni $n$. comb. generated in this study (in bold) with data from other studies (36 nucleotide sequences, 575 positions). Nodes are labelled posterior probability and, after the slash, with percent of bootstrap support in 1000 replicates in Maximum Likelihood. SA=South Africa, DRC=Democratic Republic of the Congo.

$157 \times 93 \mathrm{~mm}(300 \times 300 \mathrm{DPI})$ 


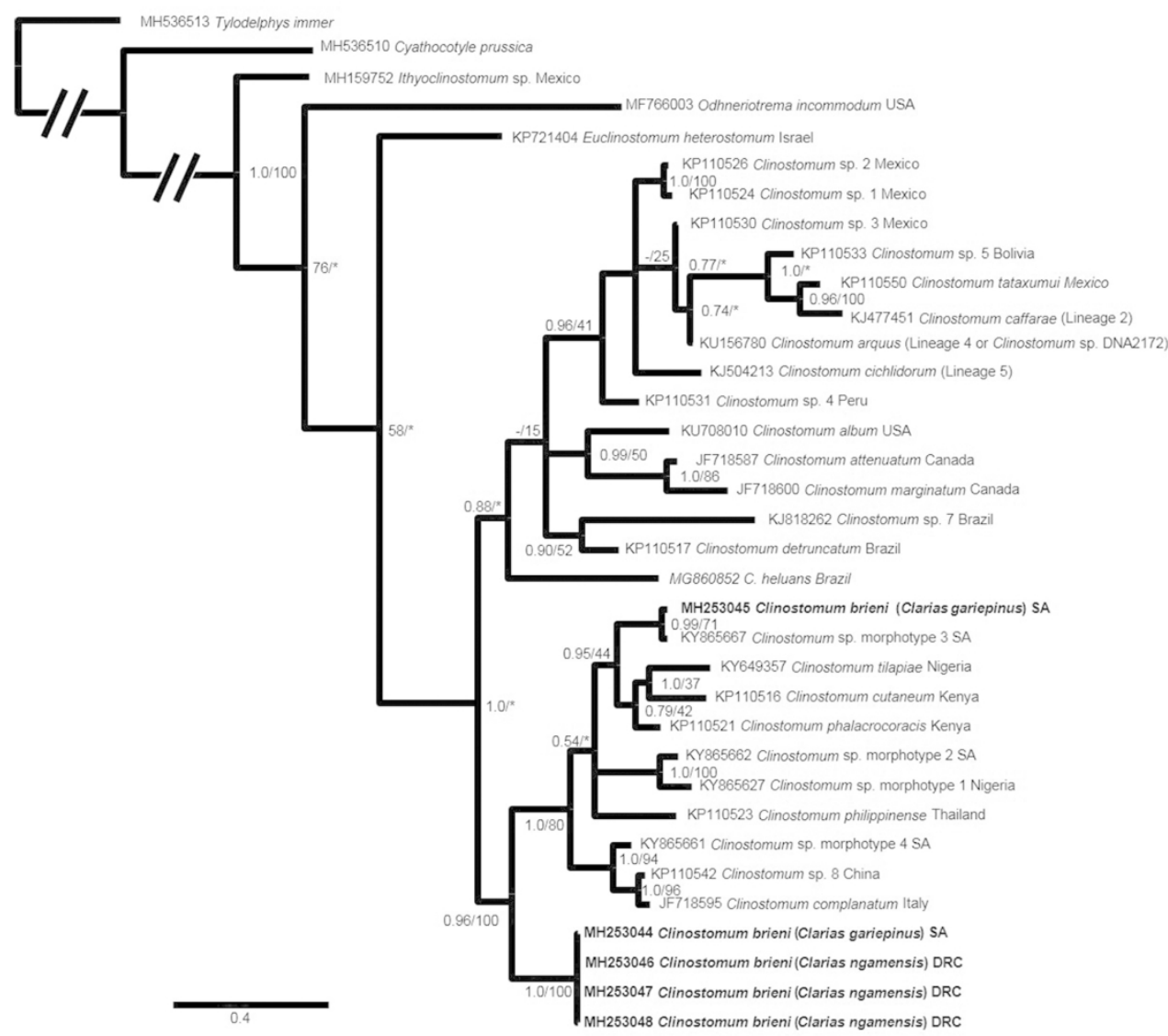

Fig. 3. Evolutionary history inferred in Bayesian Inference analysis $(G T R+G+I)$ from CO1 mtDNA of Clinostomum brieni $n$. comb. generated in this study (in bold) with data from other studies ( 37 nucleotide sequences, 473 positions). Nodes are labelled with posterior probability and, after the slash, percent of bootstrap support in 1000 replicates in separate Maximum Likelihood analysis; an asterisk indicates a clade that was not recovered with Maximum Likelihood. SA=South Africa, DRC=Democratic Republic of the Congo.

$166 \times 146 \mathrm{~mm}(300 \times 300 \mathrm{DPI})$ 


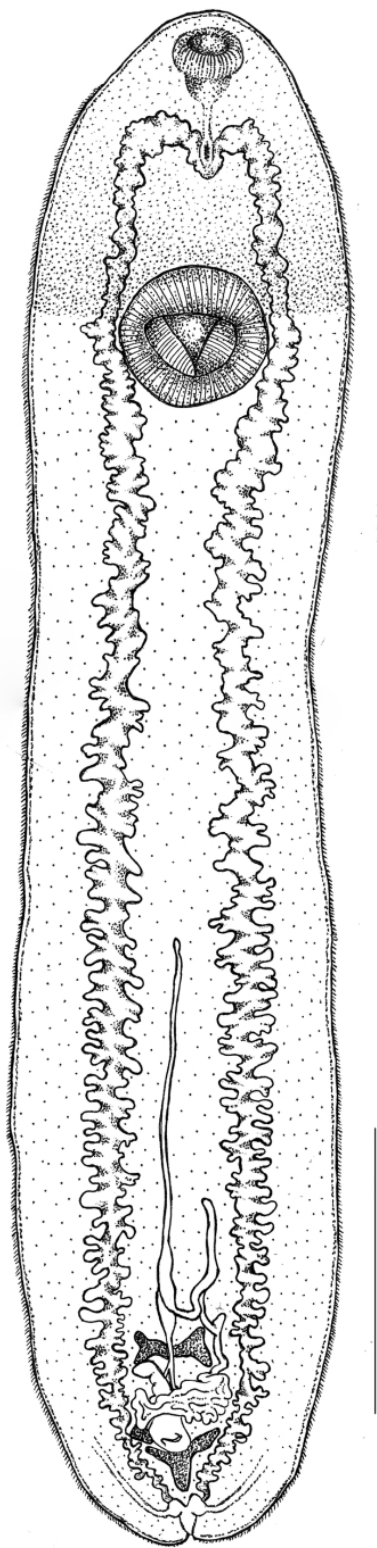

Fig. 4. Line drawing of metacercaria of Clinostomum brieni n. comb. Scale bar $=1000 \mu \mathrm{m}$. $67 \times 250 \mathrm{~mm}(300 \times 300 \mathrm{DPI})$ 
Table. 1. Morphological data of Clinostomum brieni [range (mean $\pm \mathrm{SD})$ ]

\begin{tabular}{lc}
\hline \hline Body Length & $6762-10602(8683 \pm 1425)$ \\
Body Width & $1248-1527(1392 \pm 118.3)$ \\
Body Length/Width & $4.80-8.40(6.27 \pm 1.17)$ \\
Oral Sucker (OS) Length & $172-256(218 \pm 37.91)$ \\
OS Width & $172-282(233 \pm 35.99)$ \\
OS Width/Body Width & $0.11-0.19(0.15 \pm 0.033)$ \\
Ventral Sucker (VS) Length & $622-749(676 \pm 54.08)$ \\
VS Width & $678-794(733 \pm 42.96)$ \\
VS Width/OS Width & $2.91-4.61(3.55 \pm 0.71)$ \\
VS Width/Body Width & $0.48-0.57(0.53 \pm 0.03)$ \\
Distance between OS and VS & $531-1709(1277 \pm 397.60)$ \\
Anterior Testis (AT) Length & $104-128(115 \pm 10.53)$ \\
AT Width & $317-526(426 \pm 76.8)$ \\
AT Width/Length & $2.92-4.99(3.74 \pm 0.87)$ \\
Posterior Testis (PT) Length & $114-190(145 \pm 30.57)$ \\
PT Width & $254-444(326 \pm 74.81)$ \\
PT Width/Length & $1.62-3.03(2.28 \pm 0.45)$ \\
Distance between Testes & $426-650(494 \pm 83.40)$ \\
Ovary Length & $165-200(178 \pm 12.17)$ \\
Ovary Width & $35-108(75 \pm 24.82)$ \\
Ovary Width/Length & $0.20-0.60(0.42 \pm 0.14)$ \\
Cirrus Sac (CS) Length & $437-652(577 \pm 76.76)$ \\
CS Width & $112-223(168 \pm 39.14)$ \\
CS Length/Body Length & $0.06-0.075(0.06 \pm 0.005)$ \\
\hline \hline
\end{tabular}


Table 2. Morphological data and line drawings of the genital complex of Clinostomum brieni n. comb. and in species described from the genus Clinostomoides.

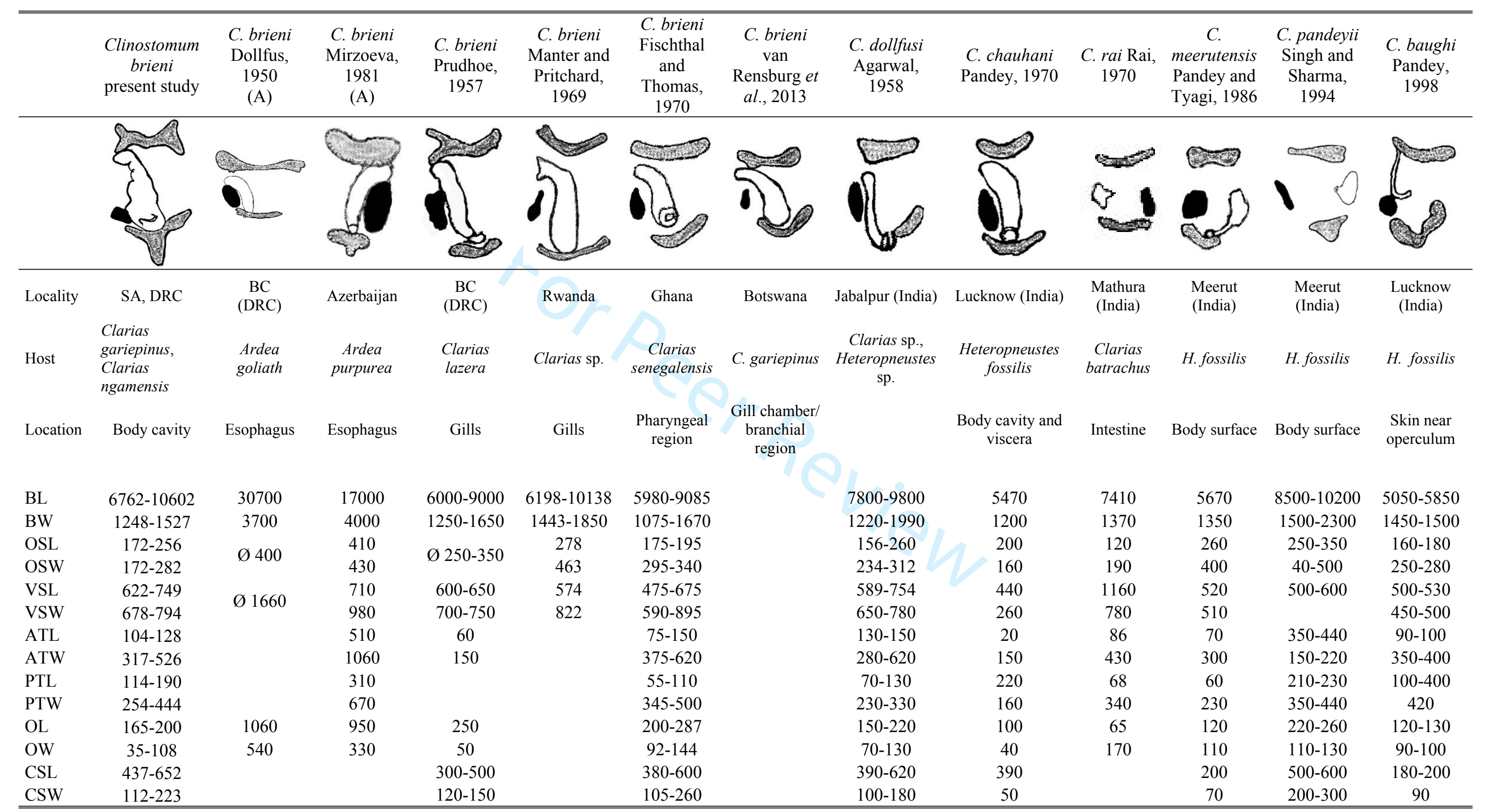

Abbreviations: BL=Body Length, BW=Body, Oral Sucker Length=OSL, Oral Sucker Width=OSW, Ventral Sucker Length=VSL, Ventral Sucker Width=VSW, Anterior Testis

Length=ATL, Anterior Testis Width=ATW, Posterior Testis Length=PTL, Posterior Testis Width=PTW, Ovary Length=OL, Ovary Width=OW, Cirrus Pouch Length=CPL, Cirrus

Pouch Width $=\mathrm{CPW}, \mathrm{SA}=$ South Africa, $\mathrm{DRC}=$ Democratic Republic of Congo, $\mathrm{BC}=$ Belgian Congo, $(\mathrm{A})=$ adult.. The line drawings were based on figures in the original publications. 